\title{
Differential Effects of the Oncogenic BRAF Inhibitor PLX4032 (Vemurafenib) and its Progenitor PLX4720 on ABCB1 Function
}

\author{
Martin Michaelis ${ }^{1,4}$, Florian Rothweiler ${ }^{1}$, Thomas Nerreter ${ }^{1}$, Marijke van Rikxoort ${ }^{1,5}$, Mohsen Sharifi ${ }^{2}$, Michael Wiese ${ }^{3}$, \\ Taravat Ghafourian ${ }^{2}$, Jindrich Cinatl jr. ${ }^{1}$ \\ ${ }^{1}$ Institut für Medizinische Virologie, Klinikum der Goethe-Universität, Paul Ehrlich-Str. 40, Germany. ${ }^{2}$ Medway School \\ of Pharmacy, Universities of Kent and Greenwich, Chatham Maritime, Kent, UK. ${ }^{3}$ Pharmaceutical Institute, University \\ of Bonn, An der Immenburg 4, Germany. ${ }^{4}$ Present address: Centre for Molecular Processing and School of Biosciences, \\ University of Kent, Canterbury, Kent, UK. ${ }^{5}$ Institute of Pharmacology and Toxicology, Biomedical Center (BMZ), \\ University of Bonn, Sigmund-Freud-Str. 25, Germany
}

Received, September 12, 2013; Revised, March 12, 2014; Accepted, March 31, 2014; Published, April 1, 2014.

\begin{abstract}
PURPOSE: The clinically approved oncogenic BRAF inhibitor PLX4032 (vemurafenib) was shown to be a substrate of the ATP-binding cassette (ABC) transporter ABCB1. Here, we compared PLX4032 and its structurally closely related precursor compound PLX4720 for their interference with ABCB1 and the ABCB1-mediated compound transport using docking and cell culture experiments. METHODS: For the docking study of PLX4032 and PLX4720 with ABCB1, we analysed binding of both compounds to mouse Abcbla and to human $\mathrm{ABCB} 1$ using a homology model of human $\mathrm{ABCB} 1$ based on the 3D structure of Abcb1a. Naturally ABCB1 expressing cells including V600E BRAF-mutated and BRAF wild-type melanoma cells and cells transduced with a lentiviral vector encoding for ABCB1 were used as cell culture models. $\mathrm{ABCB} 1$ expression and function were studied by the use of fluorescent and cytotoxic ABCB1 substrates in combination with ABCB1 inhibitors. RESULTS: Docking experiments predicted PLX4032 to interact stronger with ABCB1 than PLX4720. Experimental studies using different cellular models and structurally different $\mathrm{ABCB} 1$ substrates confirmed that PLX4032 interfered stronger with ABCB1 function than PLX4720. For example, PLX4032 $(20 \mu \mathrm{M})$ induced a 4-fold enhanced rhodamine 123 accumulation compared to PLX4720 $(20 \mu \mathrm{M})$ in ABCB1-transduced UKF-NB-3 cells and reduced the $\mathrm{IC}_{50}$ for the cytotoxic ABCB1 substrate vincristine in this model by 21-fold in contrast to a 9-fold decrease induced by PLX4720. CONCLUSIONS: PLX4032 exerted stronger effects on ABCB1-mediated drug transport than PLX4720. This indicates that small changes in a molecule can substantially modify its interaction with ABCB1, a promiscuous transporter that transports structurally different compounds.
\end{abstract}

This article is open to POST-PUBLICATION REVIEW. Registered readers (see "For Readers") may comment by clicking on ABSTRACT on the issue's contents page.

\section{INTRODUCTION}

Metastatic melanoma belongs to the most aggressive cancer diseases with median survival times below 9 months. Activating BRAF (V600E) mutations are found in 30 to $70 \%$ of melanoma patients representing a novel therapeutic target for this disease (1). PLX4032 (vemurafenib), a specific inhibitor of V600E-mutated BRAF, caused high response rates and advanced overall and progression-free survival rates in metastatic melanoma patients carrying V600E BRAF mutations. Unfortunately, resistance to PLX4032 develops quickly (2).

PLX4032 was also found to be a substrate of the ATP-binding cassette (ABC) transporter ABCB1 (also known as P-glycoprotein or MDR1) (3-5). The interaction of drugs with $\mathrm{ABCB} 1$ is important because this transporter plays important roles in the passage of drugs, xenobiotics, and food constituents through cellular and tissue barriers and consequently in their absorption, distribution, and excretion. The clinical investigation of $A B C B 1$ inhibitors had revealed that the use of compounds that interfere with $\mathrm{ABCB} 1$ function may result in toxic adverse events and complex pharmacokinetics and drug interactions that are difficult to predict $(6,7)$. Moreover, $\mathrm{ABCB} 1$ is one of the most intensively studied intrinsic and acquired resistance mechanisms in cancer cells. It is known to cause resistance to major classes of anti-cancer drugs including vinca alkaloids, taxanes, and anthracyclines $(6,7)$.

PLX4720 is a structurally related progenitor of PLX4032 that displays the same mode of binding to V600E-mutated BRAF like PLX4032 $(8,9)$.

Corresponding Author: Jindrich Cinatl jr. Institut für Medizinische Virologie, Klinikum der Goethe-Universität, Paul Ehrlich-Str. 40, Germany; E-mail Cinatl@em.unifrankfurt.de 
It differs only in one phenyl ring from PLX4032 (Figure 1). Here, we performed the first study that compared the effects of these two compounds on ABCB1 function. Docking studies suggested both PLX4032 and PLX4720 to bind to ABCB1 with
PLX4032 displaying a slightly higher affinity. Verification experiments performed using a range of different cellular models and assays confirmed that PLX4032 exerts stronger effects on ABCB1 than PLX4720.

\section{A}

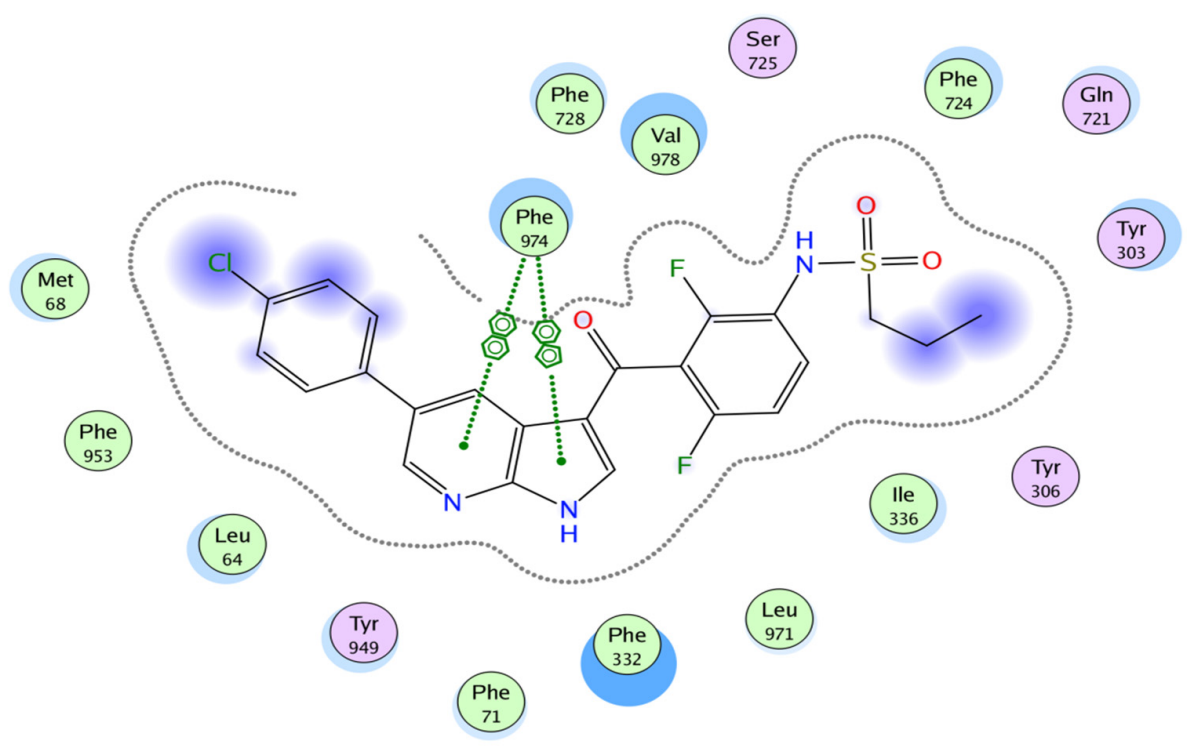

B

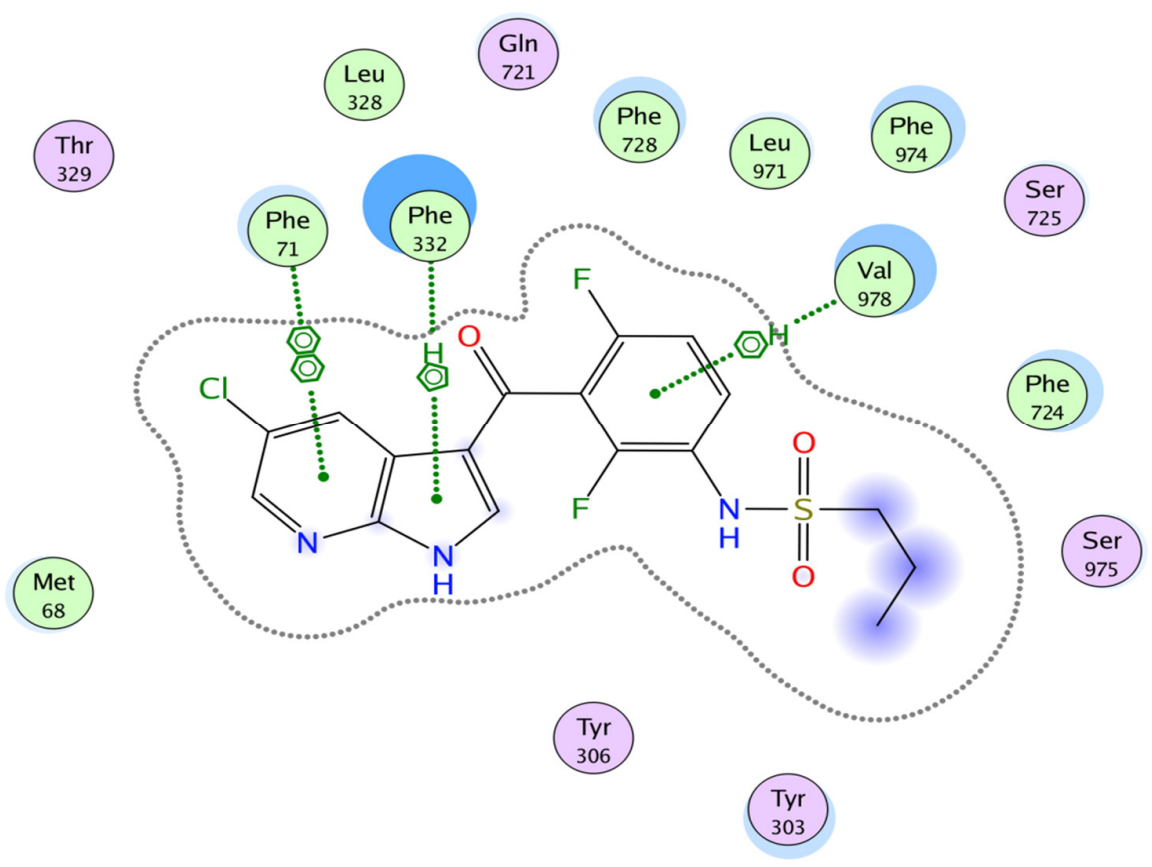

Figure 1. 2D ligand interaction diagram for PLX4032 (A) and PLX4720 (B) with mouse Abcb1a using MOE software. In this diagram, the energy cut-off for H-bond and ionic interactions were $-0.5 \mathrm{kcal} / \mathrm{mol}$ and the maximum distance for nonbonded groups was $4.5 \AA$. The polar and non-polar interactions are indicated by pink or green coloured amino acids and hydrogen bonding is indicated by green dotted arrows. The proximity contour is the dotted line surrounding the ligand. It indicates the shape of the binding site and the available space to the more outward-facing parts of the ligand. Blue shadows in some amino acids indicate the receptor exposure differences by the size and intensity of the quoits discs. The directions of the shadow indicate the directions of the amino acids towards the ligands. The blue clouds around the ligand atoms indicate the solvent exposure. 


\section{MATERIALS AND METHODS}

\section{Drugs}

Vincristine, verapamil, and PGP-4008 were obtained from Sigma-Aldrich (Deisenhofen, Germany). Rhodamine 123 was purchased from Merck Biosciences (Darmstadt, Germany). PLX4032 and PLX4720 were obtained from Selleck Chemicals via BIOZOL GmbH (Eching, Germany). Cisplatin was purchased from medac Gesellschaft für klinische Spezialpräparate $\mathrm{mbH}$ Wedel, Germany).

\section{ABCB1 docking studies}

The structure of Abcb1a, the mouse (Mus musculus) ortholog of the human $\mathrm{ABCB} 1$, had been co-crystalised with two stereo-isomers of cyclic hexapeptide inhibitors, cyclic-tris-(R)valineselenazole (QZ59-RRR) and cyclic-tris-(S)valineselenazole (QZ59-SSS) (10,11). For the docking study of PLX4032 and PLX4720 with ABCB1, we applied different approaches. We analysed binding of both compounds to mouse Abcbla and (since high or medium resolution Xray structures of human $\mathrm{ABCB} 1$ are not available) to a homology model of human ABCB1 based on the $3 \mathrm{D}$ structure of Abcbla (12). The X-ray structure of the mouse Abcbla was downloaded from the protein data bank [http://www.rcsb.org]. Docking was carried out using 1) the MOE software (MOE, version 2010.10, Chemical Computing Group Inc. Montreal, Canada) and 2) the web application at http://pgp.althotas.com (12) which performs docking using the Autodock Vina software integrated in the Molecular Docking Server (http://www.dockingserver.com).

The Mouse Abcbla structure was loaded into the MOE software, where the crystal parameters were retained and hydrogens were added. Protonatable residues were titrated using default parameters. To prepare PLX4032 and PLX4720 for docking, atomic charge and energy minimisation calculation was performed using SCF optimization through AM1 semiempirical method as implemented in the MOE software. In the MOE dock panel, the placement method was Triangle Matcher. The scoring methodology was set to London $\mathrm{dG}$ as the first and the second scoring functions. The refinement methodology was set to Forcefield, and finally, the 30 best scoring poses and the mean energies were retained. The binding site was defined in MOE software using the cocrystalised ligand QZ59-RRR. The published Xray crystallography structures $(10,11)$ were used to validate our docking model by comparing the geometries of the docked Abcb1a/QZ59-RRR structure and the structure of the Abcb1a/QZ59RRR complex from X-ray crystallography. The root-mean-square deviation (RMSD) value for this structure after superposing the docked and cocrystal structure is 0.77 . The absolute RMSD range without superposing is $0.89-6.2$ for the top 30 poses. Moreover, PDB structures of the ligands were prepared using MOE software and fed into the web server at http://pgp.althotas.com.

\section{Cell lines}

The neuroblastoma cell line UKF-NB-3 was established from bone marrow metastases of a neuroblastoma patient with MYCN-amplification (13). Its sub-line UKF-NB-3 $3^{r} \mathrm{VCR}^{10}$ was established by its adaptation to growth in the presence of vincristine $(10 \mathrm{ng} / \mathrm{mL})$ and is characterised by high $\mathrm{ABCB} 1$ expression $(13,14)$. ABCB1-overexpressing (UKF-NB-3 ${ }^{\mathrm{ABCB} 1}$, control cell line UKF-NB-3 ${ }^{\text {control }}$ ) sub-lines of UKF-NB-3 were established by lentiviral transduction with LeGO vectors as described previously (14-17). Vectors were derived using standard molecular cloning techniques as described previously $(13,14$, see also www.lentigo-vectors.de).

The melanoma cell lines Colo-679, IPC-298, MelHO, RVH-421, and SK-Mel-30 were obtained from DSMZ (Braunschweig, Germany).

All cell lines were propagated in Iscove's modified Dulbecco's medium (IMDM) supplemented with $10 \% \mathrm{FBS}, 100 \mathrm{IU} / \mathrm{ml}$ penicillin and $100 \mathrm{mg} / \mathrm{ml}$ streptomycin at $37^{\circ} \mathrm{C}$.

\section{Viability assay}

Cell viability was tested by the 3-(4,5dimethylthiazol-2-yl)-2,5-diphenyltetrazolium bromide (MTT) dye reduction assay after $120 \mathrm{~h}$ incubation, modified as described previously $(14,17)$. All experiments were performed at least in triplicate.

\section{Flow cytometry and investigation of $\mathrm{ABC}$ transporter-mediated drug efflux}

An antibody directed against ABCB1 (Alexis Biochemicals via AXXORA Deutschland, Lörrach, Germany) and a secondary antibody labelled with Phycoerythrin (R\&D, Wiesbaden, Germany) were used to detect ABCB1 expression by flow cytometry (FACSCalibur, BD Biosciences, Heidelberg, Germany).

The ABCB1-mediated drug efflux and washout kinetics were determined as described before $(14,17)$. To investigate ABCB1-mediated substance efflux, the cells were pre-incubated for 
$30 \mathrm{~min}$ with different drug concentrations. PGP4008 was used as control inhibitor of ABCB1mediated efflux. $0.1 \mu \mathrm{M}$ rhodamine 123 was added for another $30 \mathrm{~min}$. Then, cell culture medium was removed, cells were washed three times with PBS, and fresh medium containing drugs was added. After another $45 \mathrm{~min}$, the cellular fluorescence was analysed by flow cytometry. Rhodamine 123 was detected at the FL1 channel.

For wash out experiments, UKF-NB-3 ${ }^{\mathrm{ABCB} 1}$ cells were incubated for $1 \mathrm{~h}$ with rhodamine 123 $0.1 \mu \mathrm{M}$ together with different drug concentrations or with PGP4008. Subsequently, cells were washed, resuspended in supplemented medium, and the cellular fluorescence was measured at different time points $\left(\mathrm{t}_{0}, \mathrm{t}_{5}, \mathrm{t}_{15}, \mathrm{t}_{30}, \mathrm{t}_{60}, \mathrm{t}_{120}\right.$ minutes $)$ by flow cytometry.

\section{Determination of ATPase activity}

The ATPase activity of ABCB1 was determined using membrane preparations (BD Biosciences, Heidelberg, Germany) and an established kit (BD Biosciences, Heidelberg, Germany) following the manufacturer's instruction.

\section{STATISTICAL ANALYSIS}

Two groups were compared by t-test. More groups were compared by ANOVA with subsequent Student-Newman-Keuls test.

\section{RESULTS}

\section{Docking studies on the interaction of PLX4032 and PLX4720 with ABCB1}

Two docking approaches were used (web server docking, MOE) to predict the interaction of PLX4032 and PLX4720 with ABCB1. These approaches were applied using the X-ray structure of mouse Abcbla, the mouse ortholog of the human $\mathrm{ABCB} 1$, or a homology model of human ABCB1.
The interactions of PLX4032 and PLX4720 with mouse Abcbla are illustrated in Figure 1. Most amino acids in the active site are lipophilic. For PLX4032, docking energies in the top ten poses are quite high; energy of the top pose is -14.6 according to Table 1. Ligand interactions of the top ten poses showed that Phe974 is actively involved in several poses. Further examination of the top ten poses renditions indicated that the placement of the $\pi-\pi$ interaction of Phe974 is qualitatively preserved. Figure 1A is the structure of the top pose and shows the pyridine and pyrrole rings in the pyrrolo-pyridine in a strong arene-arene interaction to Phe 974. The large and intense blue shadows surrounding the amino acids Phe 332, Val 978, Tyr 303, Gln 721, Phe 724, and Phe 974, indicate that in the absence of the ligand these amino acids are highly exposed to the solvent, but the presence of the ligand greatly reduces the solvent accessible surface area. The amino acids Met 68, Leu 64, and Tyr 949 are also involved but to a lesser extent. The chlorobenzene group on the left as well as the propyl side chain on the sulphonamide illustrate degrees of solvent exposure (Figure 1A). In PLX4720, the propane sulphonamide group is also exposed to solvent (Figure 1B). The difluoroaniline has a strong arene-hydrogen bond interaction to Val 978, while the chloro-pyrrolo pyridine (left) has an arene-arene interaction to Phe 71 through the pyridine ring and arene-hydrogen bond to Phe 332 through the pyrrole ring. The receptor exposure differences are the highest for Phe 332 and Val 978 (Figure 1B).

The calculated docking energies for the 30 top poses are presented in Table 1 for mouse Abcbla and for human ABCB1. PLX4032 has a stronger interaction energy with both forms, as indicated by comparing the energies of the top pose and the average of the 30 top poses using both docking methods (web server docking, MOE) (Table 1).

Table 1. Protein interaction energies ( $\mathrm{kcal} / \mathrm{mol})$ of top scoring poses of docking mouse Abcbla or human ABCB1 with PLX4032 and PLX4720 by two different approaches. The average of the 30 top scoring poses is reported; values in brackets are the minimum and the maximum energies.

\begin{tabular}{lcccr}
\hline \multirow{2}{*}{ Receptor } & \multicolumn{2}{c}{$\begin{array}{c}\text { web server docking } \\
(\mathrm{http} / / \text { pgp.althotas.com/) }\end{array}$} & \multicolumn{2}{c}{ MOE } \\
\hline \multirow{2}{*}{ mouse Abcb1a } & PLX4032 & PLX4720 & PLX4032 & PLX4720 \\
\cline { 2 - 5 } & -10.7 & -9.0 & -10.6 & -9.91 \\
human ABCB1 & -11.2 & -10.3 & $(-14.6,-6.72)$ & $(-13.73,-5.86)$ \\
& & & -9.10 & -8.78 \\
\hline
\end{tabular}


The distances between the important groups in PLX4032 or PLX4720 and the interacting residues in mouse Abcbla are shown in Table 2. Despite that docking scores are often not very well correlated with the actual biological affinity, given that PLX4032 has one additional aromatic ring in comparison with PLX4720 and this can potentially improve binding affinity in the absence of steric hindrance, taken together, the docking results indicate a stronger interaction with $\mathrm{ABCB} 1$ for PLX4032 than for PLX4720.

\section{Effects of PLX4032 and PLX4720 on ABCB1 function}

PLX4032 and PLX4720 both enhanced accumulation of the fluorescent $\mathrm{ABCB} 1$ substrate rhodamine 123 in UKF-NB-3 ${ }^{\mathrm{ABCB} 1}$ cells (but not in empty vector-transduced control UKF-NB-3 ${ }^{\mathrm{Cer} 2}$ cells or non-transduced parental UKF-NB-3 cells that lack $\mathrm{ABCB} 1$ expression, not shown) in a concentration-dependent manner (Figure 2A). PLX4032 $(20 \mu \mathrm{M})$ induced a 4-fold enhanced rhodamine 123 accumulation compared to PLX4720 $(20 \mu \mathrm{M})$. Neither PLX4032 nor PLX4720 affected ABCB1 expression in concentrations up to $20 \mu \mathrm{M}$ after incubation for up to 5 days (data not shown).

Next, we determined the rhodamine 123 washout kinetics in the presence of PLX4032 or PLX4720. Cells were incubated with rhodamine 123 in the presence of PLX4032 or PLX4720 for $60 \mathrm{~min}$. Subsequently, cells were washed and the cellular fluorescence was monitored at different time points after the wash-out by flow cytometry. The rhodamine 123 fluorescence rapidly decreased after wash-out of PLX4032 or PLX4720 (Figure 2B). Moreover, both compounds increased the ABCB1 ATPase activity (Figure 2C).

Table 2. Distances between groups in PLX4032 or PLX4720 and the corresponding protein residues in mouse Abcb1a as indicated by the MOE docking approach

\begin{tabular}{|c|c|c|c|}
\hline Ligand & Residue & Group in PLX4720 & Distance $(\AA)$ \\
\hline \multirow[t]{3}{*}{ PLX4720 } & Phe332 & & 3.50 \\
\hline & Val978 & & 4.01 \\
\hline & Phe71 & & 3.61 \\
\hline Ligand & Residue & Group in PLX4032 & Distance $(\AA)$ \\
\hline \multirow[t]{2}{*}{ PLX4032 } & Phe974 & & 3.64 \\
\hline & Phe974 & & 3.99 \\
\hline
\end{tabular}



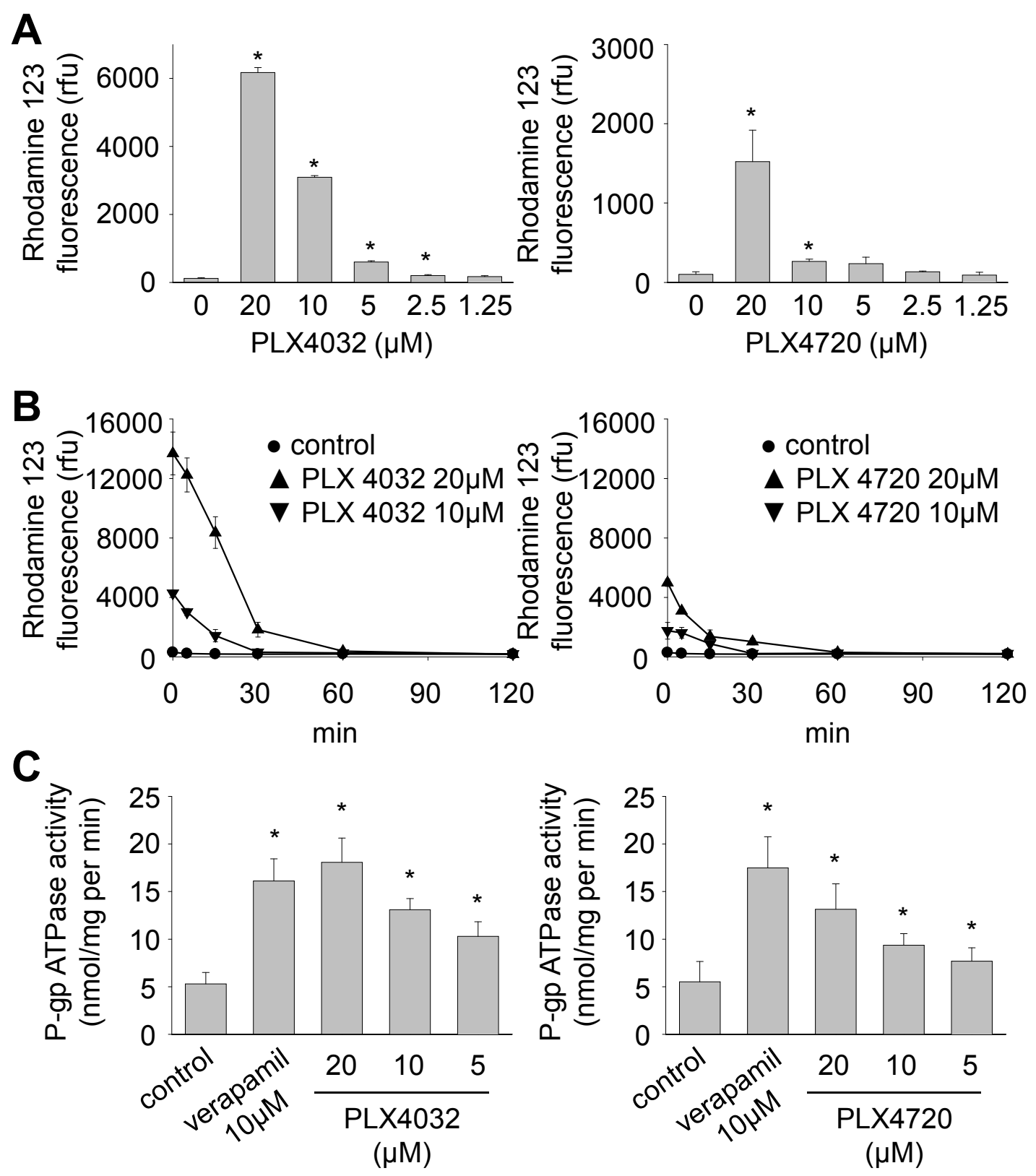

Figure 2. Interference of PLX4032 and PLX4720 with ABCB1 activity. A) Concentration-dependent influence of PLX4032 or PLX4720 on rhodamine $123(0.1 \mu \mathrm{M})$ fluorescence in UKF-NB-3 ${ }^{\mathrm{ABCB} 1}$ cells (Cells were pre-incubated for $30 \mathrm{~min}$ with the indicated PLX4032 concentrations. Then, $0.1 \mu \mathrm{M}$ rhodamine 123 was added for another 30 min. After this, cell culture medium was removed, cells were washed three times with PBS, and fresh medium containing PLX4032 was added. After another $45 \mathrm{~min}$, the cellular fluorescence was analysed by flow cytometry), B) time kinetics of rhodamine $123(0.1 \mu \mathrm{M})$ fluorescence in UKF-NB-3 ${ }^{\mathrm{ABCB} 1}$ cells in the presence of PLX4032 or PLX4720 after a 60 min pre-incubation period with subsequent wash-out of extracellular rhodamine 123 and PLX4032 or PLX4720 (control = rhodamine 123 incubation in the absence of drugs). C) ABCB1 ATPase activity in isolated membranes in the presence of PLX4032 or PLX4720 (control = activity in the absence of drugs). Verapamil, a known ABCB1 substrate, was used for comparison. * $\mathrm{P}<0.05$ relative to non-treated controls

PLX4032 and PLX4720 also increased the toxicity of the $\mathrm{ABCB} 1$ substrate vincristine in UKF-NB-3 ${ }^{\mathrm{ABCB} 1}$ cells in a concentration- dependent manner (Figure 3, Suppl. Table 1). In accordance with the cellular rhodamine 123 accumulation data, PLX4032 caused substantially 
stronger effects than PLX4720 (Figure 3, Suppl. Table 1). Neither PLX4032 nor PLX4720 affected vincristine toxicity in non-transduced UKF-NB-3 cells (Figure 3, PLX4032, Suppl. Table 2; PLX4720, Suppl. Table 3) or in UKF-NB-3 cells transduced with a control vector (Figure 3, PLX4032, Suppl. Table 4; PLX4720, Suppl. Table $5)$.

Effects of PLX4032 and PLX4720 on melanoma cells in combination with the cytotoxic ABCB1 substrate vincristine

PLX4032 and PLX4720 were further investigated in combination with the cytotoxic ABCB1 substrate vincristine in two melanoma cell lines expressing wild-type BRAF (IPC-298, SK-Mel$30)$. Both cell lines expressed ABCB1. The ABCB1 inhibitor PGP4008 (Table 3) and PLX4032 and PLX4720 decreased the vincristine $\mathrm{IC}_{50}$ in both cell lines (Table 4). Again, PLX4032 exerted stronger effects than PLX4720.

Effects of PLX4032 in combination with structurally different $\mathrm{ABCB} 1$ substrates in different $A B C B 1$ expressing cells

ABCB1 transports a broad spectrum of structurally different substances (6). Therefore, we investigated the effects of PLX4032 and PLX4720 on the sensitivity of the ABCB1-expressing cell lines UKF-NB-3 ${ }^{\mathrm{ABCB} 1}$ and UKF-NB-3 ${ }^{\mathrm{r}} \mathrm{VCR}^{10}$ to the cytotoxic $\mathrm{ABCB} 1$ substrates vincristine, paclitaxel, and actinomycin $\mathrm{D}$. The non-ABCB1 substrate CDDP was used as negative control. Both cell lines were sensitised by both compounds to all three $\mathrm{ABCB} 1$ substrates but not to cisplatin (Figure 4, Suppl. Table 6). In UKF-NB-3 ${ }^{\mathrm{ABCB} 1}$ cells, PLX4032 $10 \mu \mathrm{M}$ reduced the $\mathrm{IC}_{50}$ for vincristine by 37.81-fold, for paclitaxel by 7.61-fold, and for actinomycin D by 16.28 -fold. PLX4720 $10 \mu \mathrm{M}$ caused in UKF-NB-3 ${ }^{\mathrm{ABCB} 1}$ cells an $\mathrm{IC}_{50}$ reduction by 6.88 -fold for vincristine, by 2.73 -fold for paclitaxel, and by 3.50 -fold for actinomycin D. In UKF-NB-3 ${ }^{\mathrm{r}} \mathrm{VCR}^{10}$ cells, PLX4032 $10 \mu \mathrm{M}$ decreased the vincristine $\mathrm{IC}_{50}$ by 27.98 -fold, the paclitaxel $\mathrm{IC}_{50}$ by 4.10 -fold, and the actinomycin D $\mathrm{IC}_{50}$ by 6.06 -fold, while PLX4720 reduced the respective $\mathrm{IC}_{50}$ values by 7.19 -fold (vinctistine), 1.77-fold (paclitaxel), and 3.68-fold (actinomycin D) (Figure 4, Suppl. Table 6). The compounds did neither sensitise UKF-NB-3 cells nor UKF-NB-3 cells transduced with a control vector (serving as vector control for UKF-NB-3 ${ }^{\mathrm{ABCB} 1}$ cells) to toxicity induced by vincristine, paclitaxel, actinomycin D, or cisplatin (Figure 4, Suppl. Table 7). Taken together, these data show that PLX4032 and PLX4720 interfere with a range of structurally different ABCB1 substrates and that PLX4032 consistently exerts stronger effects on the ABCB1mediated compound transport.

\section{DISCUSSION}

PLX4032, an inhibitor of V600E-mutated BRAF, demonstrated clinical efficacy for the treatment of V600E-mutated melanoma (2) and was shown to be a substrate of $\mathrm{ABCB} 1$ (3-5), an $\mathrm{ABC}$ transporter that is involved in the regulation of the absorption, distribution, and excretion of drugs and xenobiotics as well as in cancer cell drug resistance (6).

Here, we compared PLX4032 and its structurally related progenitor compound PLX4720 for their effects on ABCB1. First, we performed docking experiments. The interaction energies and the 2D representation of the interaction plot for the top poses indicated that PLX4032 has a stronger interaction with ABCB1 than PLX4720. Both compounds interfere with ABCB1's Phe 332 and Val 978, and in addition PLX4032 has strong interaction with Phe 974.

The docking results were experimentally confirmed using UKF-NB-3 neuroblastoma cells transduced with a lentiviral vector encoding for $\mathrm{ABCB} 1$ and ABCB1-expressing UKF-NB$3^{\mathrm{r}} \mathrm{VCR}^{10}$ cells. PLX4032 and PLX4720 interfered with the transport of compounds from structurally different classes including the fluorescence dye rhodamine 123 and the cytotoxic anti-cancer drugs vincristine, paclitaxel, and actinomycin $\mathrm{D}$. These findings are quite remarkable because they show that small changes in a molecule like PLX4032 can result in a substantial change in its affinity to $\mathrm{ABCB} 1$ despite the tremendous promiscuity of this transporter that recognises substrates from a broad range of structurally very different compounds (6). Compounds that interfere with $\mathrm{ABCB} 1$ function may modify the pharmacokinetics of coadministered substances. This may result in toxic adverse events and unpredictable drug interactions (7). Therefore, compounds that display less interaction with $\mathrm{ABCB} 1$ may be favourable, in particular if administered at the same time as cancer-unrelated drugs. The situation may be less clear regarding anti-cancer therapy regimens that contain PLX4032 in combination with other anticancer drugs as proposed previously (18). 


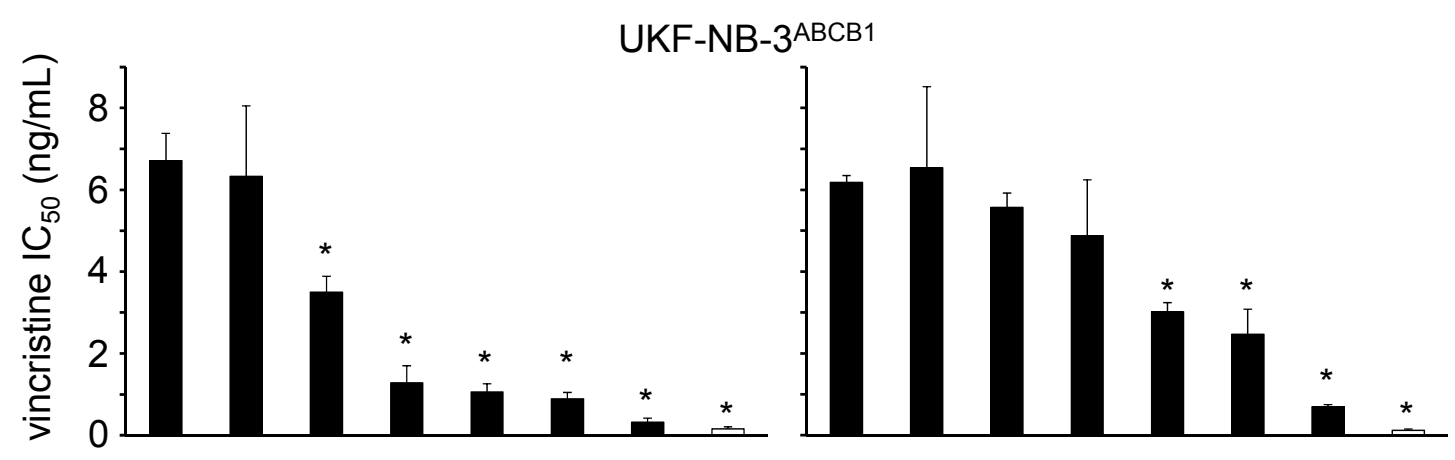

UKF-NB-3
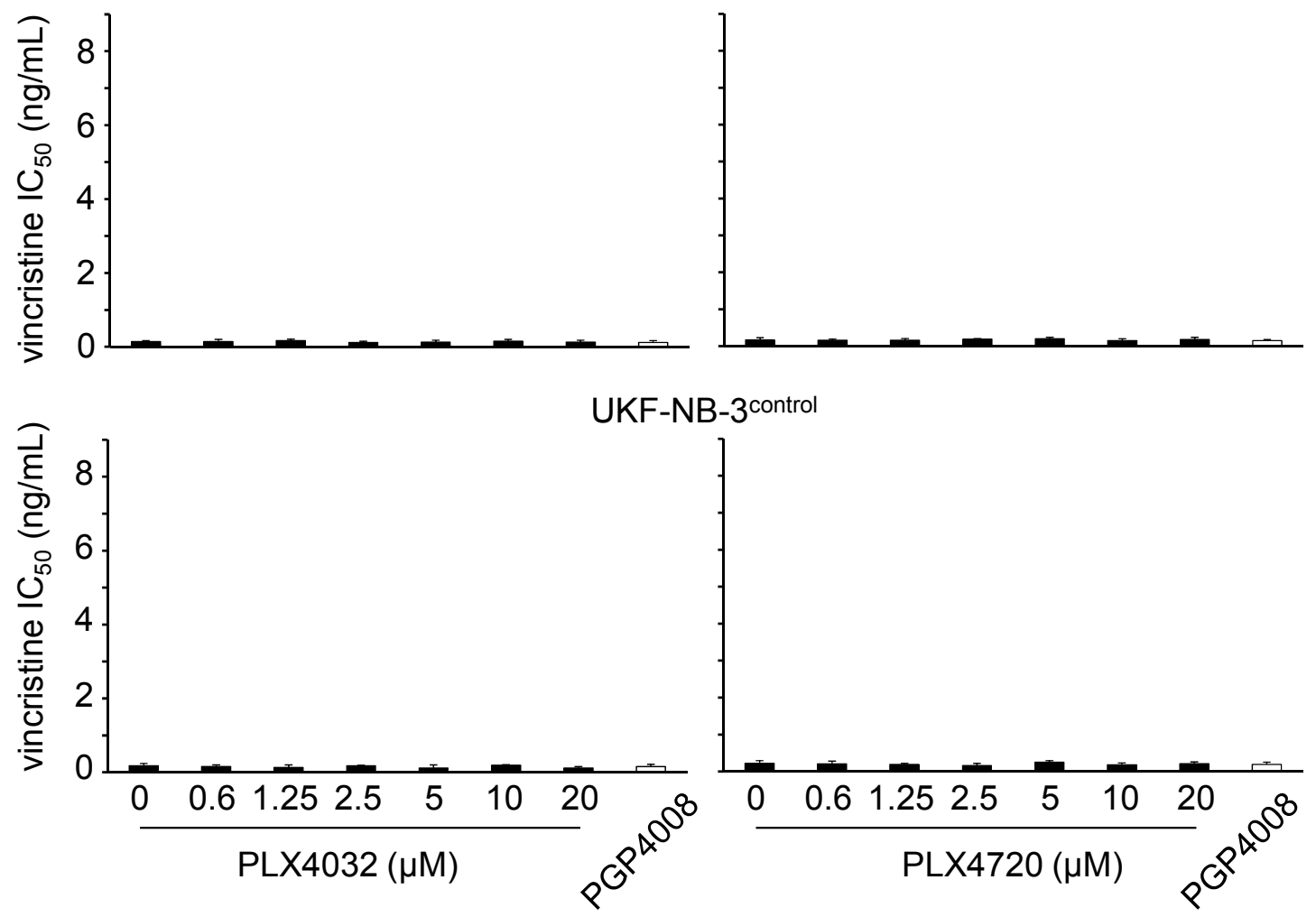

Figure 3. Influence of PLX4032 and PLX4720 on the vincristine sensitivity of UKF-NB-3 cells transduced with a lentiviral vector (UKF-NB-3 ${ }^{\mathrm{ABCB} 1}$ ), UKF-NB-3 cells, and UKF-NB-3 cells transduced with an empty lentiviral control vector (UKF-NB-3 ${ }^{\text {control }}$ ). Cell viability was determined after 5 days of incubation by MTT assay. The ABCB1 inhibitor PGP4008 $(2.5 \mu \mathrm{M})$ served as control. The values are presented in the Suppl. Tables $1-5 . * \mathrm{P}<0.05$ relative to vincristine alone.

In combination with non- $\mathrm{ABCB} 1$ substrates and/or

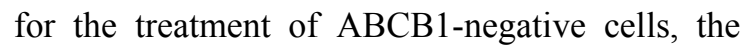
interference of PLX4032 with ABCB1 bears the risk of unfavourable side-effects due to the modification of the body distribution of xenobiotics and cancer-unrelated drugs. However, combinations of PLX4032 with other anti-cancer drugs that are ABCB1 substrates may result in synergistic effects due to inhibition of $\mathrm{ABCB} 1$ - mediated drug efflux in $\mathrm{ABCB} 1$-expressing cancer cells.

PLX4032 and PLX4720 also enhanced the effects of vincristine in the ABCB1-expressing wild-type BRAF melanoma cell lines IPC-298 and SK-MEL-30. In addition, PLX4032 increased the toxicity of the ABCB1 substrate vincristine in V600E BRAF-mutated melanoma cells (Figure 5) although we did not define the driver mechanisms underlying this combined effect. 
Table 4. Influence of PLX4032 $(20 \mu \mathrm{M})$ or PLX4720 $(20 \mu \mathrm{M})$ on the vincristine (ABCB1 substrate) concentrations that reduce cell viability by $50 \%\left(\mathrm{IC}_{50}\right)$ in the BRAF wild-type melanoma cell lines IPC298 and SK-MEL-30 that both express ABCB1.

\begin{tabular}{|c|c|c|c|c|}
\hline & $\begin{array}{c}\mathrm{IC}_{50} \text { vincristine } \\
(\mathrm{ng} / \mathrm{ml})\end{array}$ & $\begin{array}{l}\mathrm{IC}_{50} \text { vincristine in the } \\
\text { presence of } \\
\text { PLX4032/PLX4720 }\end{array}$ & $\begin{array}{l}\text { cell viability in the } \\
\text { presence of PLX } 4032 \text { or } \\
\text { PLX4720 alone } \\
(\% \text { control })\end{array}$ & fold sensitisation $^{1}$ \\
\hline \multicolumn{5}{|l|}{ PLX4032 } \\
\hline IPC298 & $2.74 \pm 0.39$ & $0.54 \pm 0.07^{*}$ & $73 \pm 7$ & 5.11 \\
\hline SK-MEL-30 & $4.57 \pm 1.49$ & $0.42 \pm 0.07^{*}$ & $85 \pm 9$ & 10.82 \\
\hline \multicolumn{5}{|l|}{ PLX4720 } \\
\hline IPC298 & $2.74 \pm 0.39$ & $0.83 \pm 0.08^{*}$ & $57 \pm 10$ & 3.32 \\
\hline SK-MEL-30 & $4.57 \pm 1.49$ & $1.50 \pm 0.62 *$ & $73 \pm 5$ & 3.04 \\
\hline
\end{tabular}
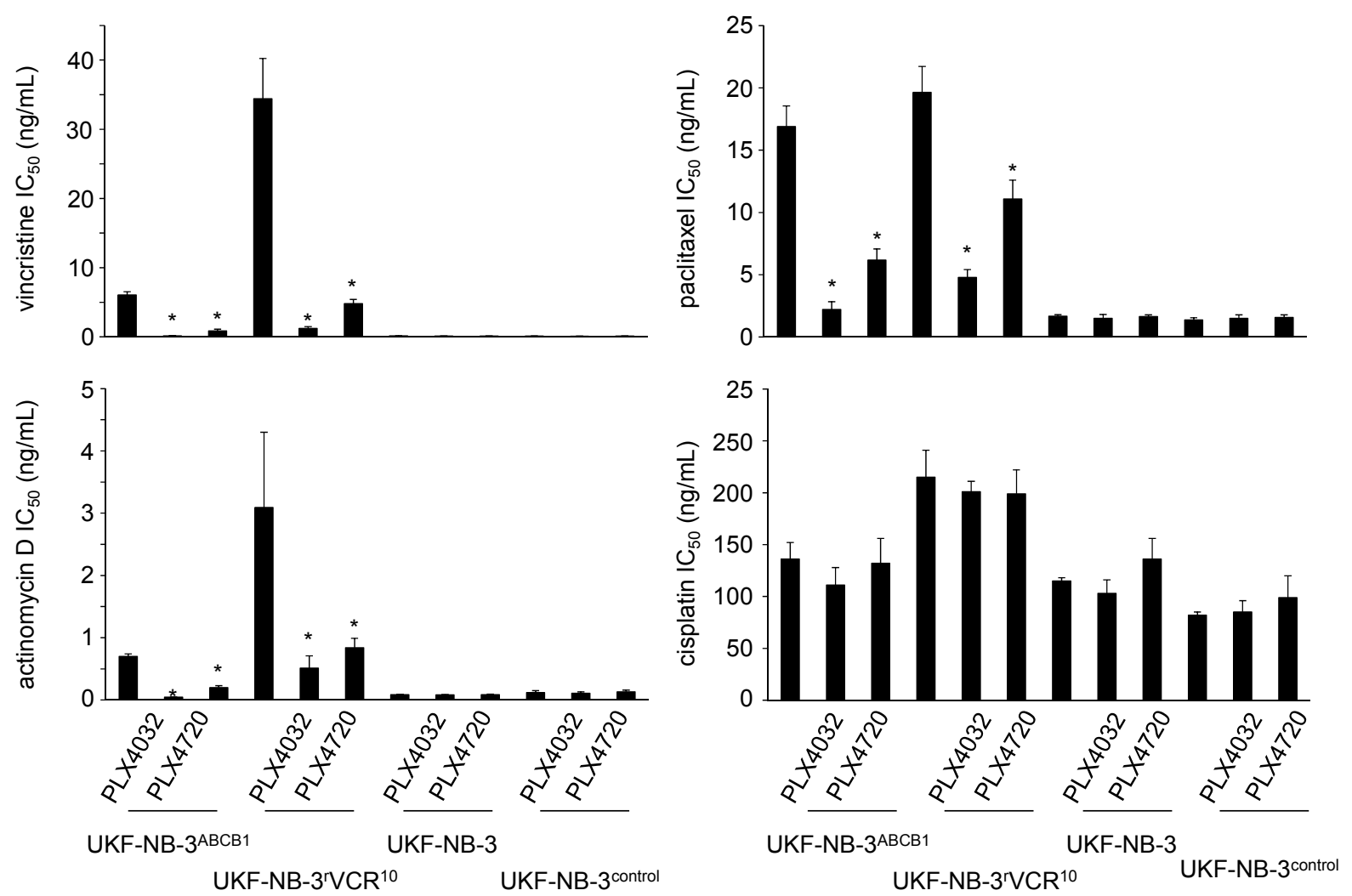

Figure 4. Effects of PLX4032 $(10 \mu \mathrm{M})$ and PLX4720 $(10 \mu \mathrm{M})$ on the sensitivity of UKF-NB-3 cells transduced with a lentiviral vector (UKF-NB-3 ${ }^{\mathrm{ABCB} 1}$ ), ABCB1-expressing UKF-NB-3 ${ }^{\mathrm{r}} \mathrm{VCR}^{10}$ cells, UKF-NB-3 cells, and UKF-NB-3 cells transduced with an empty lentiviral control vector (UKF-NB-3 ${ }^{\text {control }}$ ) to structurally different cytotoxic ABCB1 substrates. Cell viability was determined after 5 days of incubation by MTT assay. Cisplatin that is not an ABCB1 substrate served as control. The values are presented in the Suppl. Tables 6 and 7 . ${ }^{*} \mathrm{P}<0.05$ relative to the respective cytotoxic drug alone.

A rapid decrease of cellular fluorescence mediated by the ABCB1 substrate rhodamine 123 was detected after the wash-out of PLX4032 and PLX4720. Also, both compounds stimulated the 
ATPase activities of ABCB1. These findings may suggest that PLX4032 and PLX4720 are ABCB1 substrates. Thus, they are in accordance with recent publications that showed that PLX4032 is a $\mathrm{ABCB} 1$ substrate $(3,4)$. Notably, the interaction of compounds like PLX4032 and PLX4720 with ABCB1 may depend on the cellular context since PLX4720 was recently shown not to affect ABCB1 function in Ras-NIH 3T3/Mdr cells (19).

In conclusion, we show that PLX4032 exerts stronger effects on $\mathrm{ABCB} 1$ than its structurally very similar progenitor PLX4720. The findings demonstrate that small changes in a molecule can substantially modify its interaction with $\mathrm{ABCB} 1$ although $\mathrm{ABCB} 1$ is an extremely promiscuous transporter that transports a broad range of structurally different compounds.

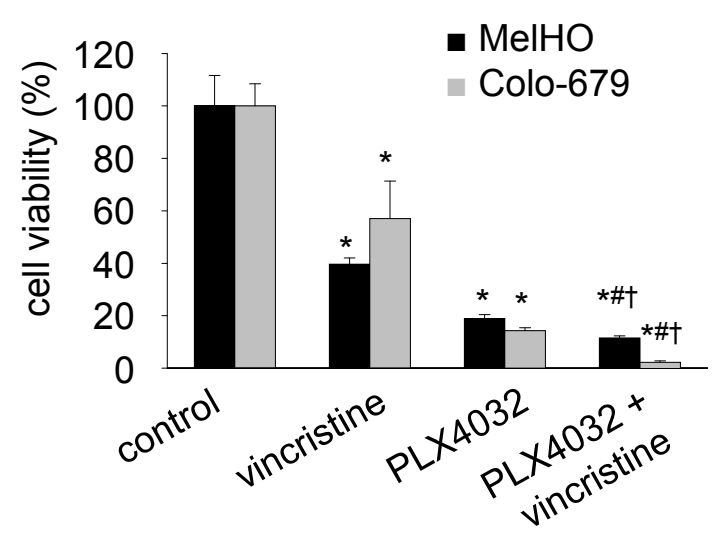

Figure 5. Influence of PLX4032 on the sensitivity of ABCB1- and ABCC1-expressing V600E BRAFmutated melanoma cells to the cytotoxic ABCB1 and ABCC1 substrate vincristine. Viability of Colo-679 or MelHO melanoma cells after $48 \mathrm{~h}$ incubation with vincristine $(10 \mathrm{ng} / \mathrm{ml})$, PLX4032 $(10 \mu \mathrm{M})$, or vincristine $(10 \mathrm{ng} / \mathrm{ml})+\mathrm{PLX} 4032(10 \mu \mathrm{M})$ relative to non-treated control. ${ }^{*} \mathrm{P}<0.05$ relative to non-treated controls; ${ }^{\#} \mathrm{P}<$ 0.05 relative to vincristine $(10 \mathrm{ng} / \mathrm{ml})$ treatment; ${ }^{\dagger} \mathrm{P}<$ 0.05 relative to PLX4032 $(10 \mu \mathrm{M})$ treatment.

\section{ACKNOWLEDGEMENTS}

The authors thank Kristoffer Weber and Boris Fehse (Forschungsabteilung Zell- und Gentherapie, Interdisziplinäre Klinik und Poliklinik für Stammzelltransplantation, Universitätsklinikum Hamburg-Eppendorf) for provision of and support with the lentiviral vectors used. Moreover, the authors thank Eva Bechtold for technical support.

The work was supported by the Hilfe für krebskranke Kinder Frankfurt e.V. and the Frankfurter Stiftung für krebskranke Kinder.

\section{REFERENCES}

1. Flaherty, K.T. and McArthur, G. BRAF, a target in melanoma: implications for solid tumor drug development. Cancer, 116:4902-4913, 2010.

2. Bollag, G., Tsai, J., Zhang, J., Zhang, C., Ibrahim, P., Nolop, K., Hirth, P. Vemurafenib: the first drug approved for BRAF-mutant cancer. Nat Rev Drug Discov, 11: 873-886, 2012.

3. Mittapalli, R.K., Vaidhyanathan, S., Sane, R., Elmquist, W.F. Impact of P-glycoprotein (ABCB1) and Breast Cancer Resistance Protein (ABCG2) on the Brain Distribution of a novel B-RAF Inhibitor: Vemurafenib (PLX4032). J Pharmacol Exp Ther, 342:33-40, 2012.

4. Durmus, S., Sparidans, R.W., Wagenaar, E., Beijnen, J.H., Schinkel, A.H. Oral availability and brain penetration of the B-RAFV600E inhibitor vemurafenib can be enhanced by the $\mathrm{P}$ GLYCOprotein (ABCB1) and breast cancer resistance protein (ABCG2) inhibitor elacridar. Mol Pharm, 9:3236-3245, 2012.

5. Wu, C.P., Sim, H.M., Huang, Y.H., Liu, Y.C., Hsiao, S.H. Overexpression of ATP-binding cassette transporter ABCG2 as a potential mechanism of acquired resistance to vemurafenib in $\mathrm{BRAF}(\mathrm{V} 600 \mathrm{E})$ mutant cancer cells. Biochem Pharmacol, 85:325-334, 2013.

6. Szakács, G., Váradi, A., Ozvegy-Laczka, C., Sarkadi, B. The role of ABC transporters in drug absorption, distribution, metabolism, excretion and toxicity (ADME-Tox). Drug Discov Today, 13:379-393, 2008.

7. Chen, K.G. and Sikic, B.I. Molecular pathways: regulation and therapeutic implications of multidrug resistance. Clin Cancer Res, 18:18631869, 2012.

8. Tsai, J., Lee, J.T., Wang, W., Zhang, J., Cho, H., Mamo, S., Bremer, R., Gillette, S., Kong, J., Haass, N.K., Sproesser, K., Li, L., Smalley, K.S., Fong, D., Zhu, Y.L., Marimuthu, A., Nguyen, H., Lam, B., Liu, J., Cheung, I., Rice, J., Suzuki, Y., Luu, C., Settachatgul, C., Shellooe, R., Cantwell, J., Kim, S.H., Schlessinger, J., Zhang, K.Y., West, B.L., Powell, B., Habets, G., Zhang, C., Ibrahim, P.N., Hirth, P., Artis, D.R., Herlyn, M., Bollag, G. Discovery of a selective inhibitor of oncogenic BRaf kinase with potent antimelanoma activity. Proc Natl Acad Sci U S A, 105:3041-3046, 2008.

9. Bollag, G., Hirth, P., Tsai, J., Zhang, J., Ibrahim, P.N., Cho, H., Spevak, W., Zhang, C., Zhang, Y., Habets, G., Burton, E.A., Wong, B., Tsang, G., West, B.L., Powell, B., Shellooe, R., Marimuthu, A., Nguyen, H., Zhang, K.Y., Artis, D.R., Schlessinger, J., Su, F., Higgins, B., Iyer, R., D'Andrea, K., Koehler, A., Stumm, M., Lin, P.S., Lee, R.J., Grippo, J., Puzanov, I., Kim, K.B., Ribas, A., McArthur, G.A., Sosman, G.A., Chapman, P.B., Flaherty, K.T., Xu, X., Nathanson, K.L., Nolop, K. Clinical efficacy of a RAF inhibitor 
needs broad target blockade in BRAF-mutant melanoma. Nature, 467:596-599, 2010.

10. Aller, S., Yu, J., Ward, A., Weng, Y., Chittaboina, S., Zhuo, R., Harrell, P.M., Trinh, Y.T., Zhang, Q., Urbatsch, I.L., Chang, G. Structure of PGlycoprotein Reveals a Molecular Basis for PolySpecific Drug Binding. Science, 323:1718-1722, 2009.

11. Gutmann, D., Ward, A., Urbatsch, I., Chang, G., Veen, $H$. Understanding polyspecificity of multidrug $\mathrm{ABC}$ transporters: closing in on the gaps in ABCB1. Trends Biochem Sci, 35:36-42, 2010.

12. Bikadi, Z., Hazai, I., Malik, D., Jemnitz, K., Veres, Z., Hari, P., Ni, Z., Loo, T.W., Clarke, D.M., Hazai, E., Mao, Q. Predicting P-glycoprotein drug transport based on support vector machine and three-dimensional crystal structure of Pglycoprotein. PLoS One, 6:e25815, 2011.

13. Kotchetkov, R., Hernáiz Driever, P., Cinatl, J., Michaelis, M., Karaskova, J., Blaheta, R., Squire, J.A., von Deimling, A., Moog, J., Cinatl, J. Jr. Increased malignant behavior in neuroblastoma cells with acquired multi-drug resistance does not depend on P-gp Expression. Int J Oncol, 27:10291037, 2005.

14. Michaelis, M., Rothweiler, F., Klassert, D., von Deimling, A., Weber, K., Fehse, B., Kammerer, B., Doerr, H.W., Cinatl, J. Jr. Reversal of Pglycoprotein-mediated multidrug resistance by the murine double minute 2 antagonist nutlin-3. Cancer Res, 69:416-421, 2009.

15. Weber, K., Bartsch, U., Stocking, C., Fehse, B. A multicolor panel of novel lentiviral "gene ontology"
(LeGO) vectors for functional gene analysis. Mol Ther, 16:698-706, 2008.

16. Weber, K., Thomaschewski, M., Warlich, M., Volz, T., Cornils, K., Niebuhr, B., Täger, M., Lütgehetmann, M., Pollok, J.M., Stocking, C., Dandri, M., Benten, D., Fehse, B. RGB marking facilitates multicolor clonal cell tracking. Nat Med, 17:504-509, 2011.

17. Rothweiler, F., Michaelis, M., Brauer, P., Otte, J., Weber, K., Fehse, B., Doerr, H.W., Wiese, M., Kreuter, J., Al-Abed, Y., Nicoletti, F., Cinatl, J. Jr. Anticancer effects of the nitric oxide-modified saquinavir derivative saquinavir-NO against multidrug-resistant cancer cells. Neoplasia, 12:1023-1030, 2010.

18. Trunzer, K., Pavlick, A.C., Schuchter, L., Gonzalez, R., McArthur, G.A., Hutson, T.E., Moschos, S.J., Flaherty, K.T., Kim, K.B., Weber, J.S., Hersey, P., Long, G.V., Lawrence, D., Ott, P.A., Amaravadi, R.K., Lewis, K.D., Puzanov, I., Lo, R.S., Koehler, A., Kockx, M., Spleiss, O., Schell-Steven, A., Gilbert, H.N., Cockey, L., Bollag, G., Lee, R.J., Joe, A.K., Sosman, J.A., Ribas A. Pharmacodynamic effects and mechanisms of resistance to vemurafenib in patients with metastatic melanoma. J Clin Oncol, 31:1767-1774, 2013.

19. Eum, K.H., Ahn, S.K., Kang, H., Lee, M. Differential inhibitory effects of two Raf-targeting drugs, sorafenib and PLX4720, on the growth of multidrug-resistant cells. Mol Cell Biochem, 372:65-74, 2013

\begin{tabular}{|c|c|c|c|}
\hline & $\begin{array}{l}\text { cell viability in the absence } \\
\text { of vincristine }(\%)\end{array}$ & $\begin{array}{c}\mathrm{IC}_{50} \text { vincristine } \\
(\mathrm{ng} / \mathrm{mL})^{1}\end{array}$ & $\begin{array}{l}\text { fold sensitisation relative to vincristine } \\
\text { alone }\end{array}$ \\
\hline \multicolumn{4}{|l|}{ PLX4032 $(\mu \mathrm{M})$} \\
\hline 0 & $100.00 \pm 0.00$ & $6.71 \pm 0.67$ & 1.00 \\
\hline 0.625 & $91.56 \pm 10.38$ & $6.33 \pm 1.72$ & 1.06 \\
\hline 1.25 & $82.88 \pm 7.46$ & $3.50 \pm 0.39 *$ & 1.92 \\
\hline 2.5 & $80.77 \pm 4.14$ & $1.28 \pm 0.42^{*}$ & 5.24 \\
\hline 5 & $89.86 \pm 5.65$ & $1.06 \pm 0.20^{*}$ & 6.33 \\
\hline 10 & $82.75 \pm 14.95$ & $0.89 \pm 0.16^{*}$ & 7.54 \\
\hline 20 & $90.69 \pm 4.42$ & $0.32 \pm 0.10^{*}$ & 20.97 \\
\hline PGP4008 $2.5 \mu \mathrm{M}$ & $79.42 \pm 14.29$ & $0.16 \pm 0.05^{*}$ & 41.94 \\
\hline \multicolumn{4}{|l|}{$\operatorname{PLX4720}(\mu \mathrm{M})$} \\
\hline 0 & $100.00 \pm 0.00$ & $6.18 \pm 0.17$ & 1.00 \\
\hline 0.625 & $100.61 \pm 6.97$ & $6.54 \pm 1.98$ & 0.94 \\
\hline 1.25 & $89.23 \pm 9.90$ & $5.57 \pm 0.35$ & 1.11 \\
\hline 2.5 & $81.50 \pm 9.19$ & $4.88 \pm 1.36$ & 1.26 \\
\hline 5 & $100.00 \pm 16.87$ & $3.02 \pm 0.22 *$ & 2.05 \\
\hline 10 & $75.86 \pm 7.00$ & $2.47 \pm 0.61^{*}$ & 2.50 \\
\hline 20 & $76.00 \pm 11.31$ & $0.70 \pm 0.05^{*}$ & 8.83 \\
\hline PGP4008 $2.5 \mu \mathrm{M}$ & $82.24 \pm 20.45$ & $0.12 \pm 0.03^{*}$ & 51.50 \\
\hline
\end{tabular}


Suppl. Table 2. Influence of PLX4032 or the ABCB1 inhibitor PGP4008 on the concentration of the ABCB1 substrate vincristine that decreases the viability of UKF-NB-3 cells by $50 \%\left(\mathrm{IC}_{50}\right)$.

\begin{tabular}{lccc}
\hline PLX4032 $(\mu \mathrm{M})$ & $\begin{array}{c}\text { cell viability in the } \\
\text { absence of vincristine }(\%)\end{array}$ & $\begin{array}{c}\mathrm{IC}_{50} \text { vincristine } \\
(\mathrm{ng} / \mathrm{mL})^{1}\end{array}$ & $\begin{array}{c}\text { fold sensitisation relative to vincristine } \\
\text { alone }\end{array}$ \\
\hline 0 & $100.00 \pm 0.00$ & $0.14 \pm 0.03$ & 1.00 \\
0.625 & $95.25 \pm 7.88$ & $0.14 \pm 0.06$ & 1.00 \\
1.25 & $87.19 \pm 9.71$ & $0.17 \pm 0.04$ & 0.82 \\
2.5 & $74.61 \pm 8.69$ & $0.12 \pm 0.03$ & 1.17 \\
5 & $75.28 \pm 7.79$ & $0.13 \pm 0.05$ & 1.08 \\
10 & $70.37 \pm 6.21$ & $0.15 \pm 0.05$ & 0.93 \\
20 & $45.32 \pm 8.17$ & $0.13 \pm 0.05$ & 1.08 \\
PGP4008 $(\mu \mathrm{M})$ & & & \\
2.5 & $77.82 \pm 14.09$ & $0.12 \pm 0.05$ & 1.17 \\
\hline
\end{tabular}

${ }^{1}$ in the presence of the indicated PLX4032 or PGP4008 concentrations

Suppl. Table 3. Influence of PLX4720 or the ABCB1 inhibitor PGP4008 on the concentration of the ABCB1 substrate vincristine that decreases the viability of UKF-NB-3 cells by $50 \%\left(\mathrm{IC}_{50}\right)$.

\begin{tabular}{lccc}
\hline PLX4720 $(\mu \mathrm{M})$ & $\begin{array}{c}\text { cell viability in the } \\
\text { absence of vincristine }(\%)\end{array}$ & $\begin{array}{c}\mathrm{IC}_{50} \text { vincristine } \\
(\mathrm{ng} / \mathrm{mL})^{1}\end{array}$ & $\begin{array}{c}\text { fold sensitisation relative to vincristine } \\
\text { alone }\end{array}$ \\
\hline 0 & $100.00 \pm 0.00$ & $0.17 \pm 0.06$ & 1.00 \\
0.625 & $95.19 \pm 12.38$ & $0.16 \pm 0.03$ & 1.06 \\
1.25 & $82.56 \pm 9.96$ & $0.16 \pm 0.05$ & 1.06 \\
2.5 & $88.15 \pm 11.16$ & $0.19 \pm 0.02$ & 0.89 \\
5 & $80.06 \pm 9.22$ & $0.20 \pm 0.04$ & 0.85 \\
10 & $61.51 \pm 12.87$ & $0.15 \pm 0.05$ & 1.13 \\
20 & $40.83 \pm 10.33$ & $0.18 \pm 0.06$ & 0.94 \\
PGP4008 $(\mu \mathrm{M})$ & & & \\
2.5 & $74.64 \pm 16.51$ & $0.15 \pm 0.03$ & 1.13 \\
\hline
\end{tabular}

${ }^{1}$ in the presence of the indicated PLX4720 or PGP4008 concentrations

Suppl. Table 4. Influence of PLX4032 or the ABCB1 inhibitor PGP4008 on the concentration of the ABCB1 substrate vincristine that decreases the viability of UKF-NB-3 cells transduced with an empty control vector (as comparison to UKF-NB-3 $\left.{ }^{\mathrm{ABCB} 1}\right)$ by $50 \%\left(\mathrm{IC}_{50}\right)$.

\begin{tabular}{lccc}
\hline PLX4032 $(\mu \mathrm{M})$ & $\begin{array}{c}\text { cell viability in the } \\
\text { absence of vincristine }(\%)\end{array}$ & $\begin{array}{c}\mathrm{IC}_{50} \text { vincristine } \\
(\mathrm{ng} / \mathrm{mL})^{1}\end{array}$ & $\begin{array}{c}\text { fold sensitisation relative to vincristine } \\
\text { alone }\end{array}$ \\
\hline 0 & $100.00 \pm 0.00$ & $0.18 \pm 0.06$ & 1.00 \\
0.625 & $92.86 \pm 11.74$ & $0.16 \pm 0.04$ & 1.13 \\
1.25 & $80.49 \pm 10.82$ & $0.13 \pm 0.07$ & 1.38 \\
2.5 & $81.19 \pm 9.96$ & $0.18 \pm 0.01$ & 1.00 \\
5 & $78.67 \pm 4.51$ & $0.12 \pm 0.08$ & 1.50 \\
10 & $72.57 \pm 4.19$ & $0.19 \pm 0.02$ & 0.95 \\
20 & $40.67 \pm 7.73$ & $0.12 \pm 0.04$ & 1.50 \\
PGP4008 $(\mu \mathrm{M})$ & & & 1.13 \\
2.5 & $76.68 \pm 15.01$ & $0.16 \pm 0.06$ & \\
\hline 1 in the presence of the indicated PLX4032 or PGP4008 concentrations & \\
\hline
\end{tabular}

${ }^{1}$ in the presence of the indicated PLX4032 or PGP4008 concentrations 
Suppl. Table 5. Influence of PLX4720 or the ABCB1 inhibitor PGP4008 on the concentration of the ABCB1 substrate vincristine that decreases the viability of UKF-NB-3 cells transduced with an empty control vector (as comparison to UKF-NB-3 $\left.3^{\mathrm{ABCB} 1}\right)$ by $50 \%\left(\mathrm{IC}_{50}\right)$.

\begin{tabular}{lccc}
\hline PLX4720 $(\mu \mathrm{M})$ & $\begin{array}{c}\text { cell viability in the } \\
\text { absence of vincristine }(\%)\end{array}$ & $\begin{array}{c}\mathrm{IC}_{50} \text { vincristine } \\
(\mathrm{ng} / \mathrm{mL})^{1}\end{array}$ & $\begin{array}{c}\text { fold sensitisation relative to vincristine } \\
\text { alone }\end{array}$ \\
\hline 0 & $100.00 \pm 0.00$ & $0.22 \pm 0.07$ & 1.00 \\
0.625 & $90.26 \pm 7.84$ & $0.20 \pm 0.08$ & 1.10 \\
1.25 & $96.88 \pm 5.95$ & $0.19 \pm 0.03$ & 1.16 \\
2.5 & $77.89 \pm 6.09$ & $0.16 \pm 0.06$ & 1.38 \\
5 & $75.31 \pm 9.01$ & $0.25 \pm 0.04$ & 0.88 \\
10 & $66.28 \pm 14.72$ & $0.18 \pm 0.05$ & 1.22 \\
20 & $35.16 \pm 12.63$ & $0.21 \pm 0.05$ & 1.05 \\
PGP4008 $(\mu \mathrm{M})$ & $79.65 \pm 16.96$ & & 1.16 \\
2.5 & & $0.19 \pm 0.06$ & \\
\hline
\end{tabular}

${ }^{1}$ in the presence of the indicated PLX4720 or PGP4008 concentrations

Suppl Table 6. Viability of the ABCB1-expressing cell lines UKF-NB-3 ${ }^{\mathrm{ABCB} 1}$ or UKF-NB-3 ${ }^{\mathrm{r}} \mathrm{VCR}^{10}$ after treatment with vincristine, paclitaxel, actinomycin D (cytotoxic ABCB1 substrates), or cisplatin (no ABCB1 substrate) in the absence or presence of PLX4032 $(10 \mu \mathrm{M})$ or PLX4720 $(10 \mu \mathrm{M})$, determined by MTT assay after a 5 day incubation period.

\begin{tabular}{|c|c|c|c|c|}
\hline \multirow[b]{2}{*}{ Cell line } & \multicolumn{4}{|c|}{ Concentration that inhibits cell viability by $50 \%\left(\mathrm{IC}_{50}\right)$} \\
\hline & $\begin{array}{l}\text { vincristine } \\
(\mathrm{ng} / \mathrm{mL})\end{array}$ & $\begin{array}{c}\text { paclitaxel } \\
(\mathrm{ng} / \mathrm{mL})\end{array}$ & $\begin{array}{l}\text { actinomycin } \\
\mathrm{D}(\mathrm{ng} / \mathrm{mL})\end{array}$ & $\begin{array}{l}\text { cisplatin } \\
\text { (ng/mL) }\end{array}$ \\
\hline UKF-NB-3 ${ }^{\mathrm{ABCB} 1}$ & $6.05 \pm 0.48$ & $16.89 \pm 1.65$ & $0.70 \pm 0.04$ & $136 \pm 16$ \\
\hline+ PLX4032 $(91 \pm 3 \%)^{1}$ & $\begin{array}{l}0.16 \pm 0.05^{2} \\
\quad(37.81)^{3}\end{array}$ & $\begin{array}{c}2.22 \pm 0.62^{2} \\
(7.61)\end{array}$ & $\begin{array}{c}0.043 \pm 0.004^{2} \\
(16.28)\end{array}$ & $\begin{array}{c}111 \pm 17 \\
(1.23)\end{array}$ \\
\hline$+\operatorname{PLX} 4720(76 \pm 5 \%)$ & $\begin{array}{l}0.88 \pm 0.23^{2} \\
\quad(6.88)\end{array}$ & $\begin{array}{c}6.18 \pm 0.89^{2} \\
(2.73)\end{array}$ & $\begin{array}{c}0.20 \pm 0.03^{2} \\
(3.50)\end{array}$ & $\begin{array}{c}132 \pm 24^{2} \\
(1.03)\end{array}$ \\
\hline UKF-NB- $3^{r} V_{C R}{ }^{10}$ & $34.42 \pm 5.80$ & $19.64 \pm 2.07$ & $3.09 \pm 1.21$ & $215 \pm 26$ \\
\hline + PLX4032 (90 $\pm 3 \%)$ & $\begin{array}{c}1.23 \pm 0.26^{2} \\
(27.98)\end{array}$ & $\begin{array}{c}4.79 \pm 0.63^{2} \\
(4.10)\end{array}$ & $\begin{array}{c}0.51 \pm 0.20^{2} \\
\quad(6.06)\end{array}$ & $\begin{array}{c}201 \pm 10 \\
(1.07)\end{array}$ \\
\hline+ PLX4720 (83 $\pm 10 \%)$ & $\begin{array}{c}4.79 \pm 0.63^{2} \\
(7.19)\end{array}$ & $\begin{array}{c}11.07 \pm 1.53^{2} \\
(1.77)\end{array}$ & $\begin{array}{c}0.84 \pm 0.15^{2} \\
(3.68)\end{array}$ & $\begin{array}{c}199 \pm 23^{2} \\
(1.08)\end{array}$ \\
\hline
\end{tabular}

${ }^{1}$ Cell viability in the presence of PLX4032 $(10 \mu \mathrm{M})$ or PLX4720 $(10 \mu \mathrm{M})$ alone relative to non-treated cells

${ }^{2} \mathrm{p}<0.05$ relative to the $\mathrm{IC}_{50}$ value in the absence of PLX4032 and PLX4720

${ }^{3}$ Fold sensitisation relative to cytotoxic drug alone 
Suppl. Table 7. Viability of UKF-NB-3 or UKF-NB-3 $3^{\text {control }}$ (UKF-NB-3 cells transduced with an empty vector serving as control to UKF-NB-3 ${ }^{\mathrm{ABCB} 1}$ ) cells after treatment with vincristine, paclitaxel, actinomycin D (cytotoxic ABCB1

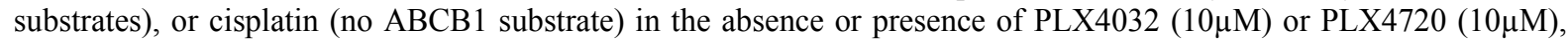
determined by MTT assay after a 5 day incubation period.

\begin{tabular}{|c|c|c|c|c|}
\hline \multirow[b]{2}{*}{ Cell line } & \multicolumn{4}{|c|}{ Concentration that inhibits cell viability by $50 \%\left(\mathrm{IC}_{50}\right)$} \\
\hline & $\begin{array}{l}\text { vincristine } \\
(\mathrm{ng} / \mathrm{mL})\end{array}$ & $\begin{array}{c}\text { paclitaxel } \\
\text { (ng/mL) }\end{array}$ & $\begin{array}{l}\text { actinomycin } \\
\mathrm{D}(\mathrm{ng} / \mathrm{mL})\end{array}$ & $\begin{array}{l}\text { cisplatin } \\
\text { (ng/mL) }\end{array}$ \\
\hline UKF-NB-3 & $0.14 \pm 0.05$ & $1.68 \pm 0.12$ & $0.083 \pm 0.002$ & $115 \pm 3$ \\
\hline$+\operatorname{PLX} 4032(72 \pm 7 \%)^{1}$ & $\begin{array}{c}0.12 \pm 0.03 \\
(1.17)^{2}\end{array}$ & $\begin{array}{l}1.51 \pm 0.30 \\
\quad(1.11)\end{array}$ & $\begin{array}{c}0.080 \pm 0.007 \\
(1.04)\end{array}$ & $\begin{array}{c}103 \pm 13 \\
(1.12)\end{array}$ \\
\hline+ PLX4720 (64 $\pm 7 \%)$ & $\begin{array}{c}0.11 \pm 0.04 \\
\quad(1.27)\end{array}$ & $\begin{array}{l}1.65 \pm 0.14 \\
\quad(1.02)\end{array}$ & $\begin{array}{c}0.084 \pm 0.009 \\
(1.02)\end{array}$ & $\begin{array}{c}136 \pm 20 \\
(0.85)\end{array}$ \\
\hline UKF-NB-3 $3^{\text {control }}$ & $0.12 \pm 0.02$ & $1.38 \pm 0.17$ & $0.12 \pm 0.03$ & $82 \pm 3$ \\
\hline$+\operatorname{PLX} 4032(88 \pm 3 \%)$ & $\begin{array}{c}0.10 \pm 0.03 \\
(1.20)\end{array}$ & $\begin{array}{l}1.50 \pm 0.29 \\
\quad(0.92)\end{array}$ & $\begin{array}{c}0.11 \pm 0.02 \\
\quad(1.09)\end{array}$ & $\begin{array}{c}85 \pm 11 \\
(0.96)\end{array}$ \\
\hline$+\operatorname{PLX} 4720(75 \pm 4 \%)$ & $\begin{array}{l}0.13 \pm 0.02 \\
(0.92)\end{array}$ & $\begin{array}{l}1.56 \pm 0.23 \\
\quad(0.88)\end{array}$ & $\begin{array}{c}0.13 \pm 0.03 \\
(0.92)\end{array}$ & $\begin{array}{c}99 \pm 21 \\
(0.83)\end{array}$ \\
\hline
\end{tabular}


Table 3. ABCB1 expression in melanoma cells and the influence of the ABCB1 inhibitor PGP4008 (2.5 $\mu \mathrm{M})$ on the concentration of the ABCB1 substrate vincristine that decreases the viability of melanoma cells by $50 \%\left(\mathrm{IC}_{50}\right)$.

\begin{tabular}{|c|c|c|c|c|c|c|}
\hline \multirow[b]{2}{*}{ Cell line } & \multirow[b]{2}{*}{$\begin{array}{l}\text { BRAF } \\
\text { status }\end{array}$} & \multicolumn{2}{|c|}{ ABCB1 expression } & \multicolumn{2}{|c|}{$\mathrm{IC}_{50}$ vincristine $(\mathrm{ng} / \mathrm{ml})$} & \multirow[b]{2}{*}{$\begin{array}{c}\text { fold } \\
\text { sensitisation }^{2}\end{array}$} \\
\hline & & & $\mathrm{RFU}^{1}$ & & + PGP4008 & \\
\hline IPC298 & wild-type & yes & $27 \pm 9$ & $2.74 \pm 0.39$ & $0.75 \pm 0.42^{3}(79 \pm 3)^{4}$ & 3.65 \\
\hline SK-Mel-30 & wild-type & yes & $88 \pm 15$ & $4.57 \pm 1.49$ & $0.92 \pm 0.33^{3}(91 \pm 10)$ & 4.99 \\
\hline \multicolumn{7}{|c|}{$\begin{array}{l}{ }^{1} \mathrm{RFU} \text {, relative fluorescence units (background fluorescence determined by t } \\
{ }^{2} \mathrm{IC}_{50} \text { vincristine/ } \mathrm{IC}_{50} \text { vincristine in the presence of PGP4008 } \\
{ }^{3} \mathrm{P}<0.05 \text { relative to vincristine alone } \\
{ }^{4} \text { cell viability (\% non-treated control) in the presence of PGP4008 alone }\end{array}$} \\
\hline
\end{tabular}

